\title{
The Construction and Evaluation of Model of Analytical Thinking Skill Training
}

\author{
Paiboon Kaittikomol ${ }^{1}$, Pairoaj Tiranathanakul ${ }^{2}$, Sudjit Montaku ${ }^{3}$ \\ ${ }^{1}$ Chief Executive of Media Arts and Media Technology program \\ King Mongkut's University of Technology Thonburi, Bangkok, Thailand \\ ${ }^{2}$ Faculty of Industrial Education and Technology \\ King Mongkut's University of Technology Thonburi Bangkok, Thailand \\ ${ }^{3}$ Department of computer science, Faculty of Science \\ Muban Chom Bueng Rajabhat University \\ 1paiboon.kia@kmutt.ac.th \\ ${ }^{3}$ sudjit2004@yahoo.com
}

\begin{abstract}
The purpose of this research was to construct and evaluate the Model of Analytical Thinking Skill Training Process. The model was employed with 5 steps in the classroom situation: 1) Warm up, 2) Demonstrate the skills, 3) Step by step coaching, 4) Full step coaching, and 5) Evaluation. The techniques used to develop analytical thinking skill were D.M.I.H. (Differentiation, Mining, Integration and Hierarchy) with Activated coaching. The content in the model was related to Sternberg's theory : the ability of analytical thinking skill. The results of this research were as follows: 1) The efficiency of model was $77.05 / 78.82,2$ ) After using model, the students' analytical thinking scores were significantly increased at .05 level,. 3) The students' satisfaction was at a high level.
\end{abstract}

Key words: Training model, D.M.I.H. process, Analytical Thinking Skill

\section{Background}

The intellectual application is the uses of cognitive competency by applying brain or thought. The cognitive competency is the thought ability through cognitive skill, and thinking skill in decision making or problem solving, reasoning, critical thinking, representing, and learning. The cognitive competency was known as cognitive domain from Bloom Taxonomy such as knowledge, comprehension, application analysis, synthesis, and evaluation. However, the cognitive competency will occur after the level of comprehension. It is the step of competency occurrence with main skills, essential attitudes and related working performance skills integrated into the moving mechanics towards achievement from thinking process qualitatively and effectively [1].

From the former research, [2] there are models of Analytical thinking skill training process as shown in the figure 1 .

\section{Model of Analytical Skill Training Process}

The training process of analytical thinking skill is consisted of 5 steps as follows: 


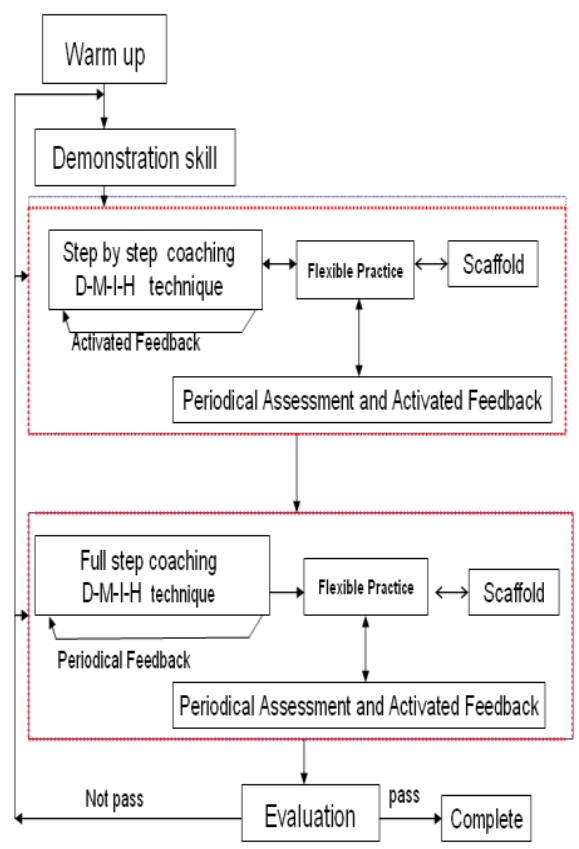

Figure 1: Model of Analytical Thinking Skill Training Process

1.1 Warm up: this step is that the in structor explains the meanings and skills of analytical thinking. The instructor also presents the ability of analytical thinking and how it is beneficial and essential. For examples, the instructor used to compare so that the differences can be seen between a person with or without the ability in analytical thinking in a role-playing situation.

1.2 Demonstrate: the instructor demonstrates the skills based on D.M.I.H. process (Differentiate, Mining, Integration, Hierarchical) which is the technical process of organizing analytical thinking skill development with four sub-step as follow:

1.2.1 Differentiation step with brain storming.

1.2.2 Mining step by concept chart creation.
1.2.3 Integration step by network chart creation.

\subsubsection{Hierarchy step by hierarchy chart creation.}

1.3 Step by step coaching: the instructor coaches the students step by step with flexible practice by following the substep of analytical thinking skill development through the process of D.M.I.H.

1.4 The full step coaching: this step get students to do the training from Doing by themselves. Such flexible practice will give the students opportunities to complete all steps of analytical thinking skill developing process known as D.M.I.H.

1.5 Evaluation: the students do the test with appropriate content for the level of students and general information related to daily life.

The analytical Thinking Skill was effective toward students in computer programming. There was high number of students who were studying computer programming being poor in analytical thinking skills. Thus the researchers want to construction the model of analytical thinking skill training in order to improve students' analytical thinking skills and to increase their computer programming.

\section{Research objectives}

2.1 To construct the Model of Analytical thinking Skill based on D.I.M.H. organizing analytical thinking skill development process.

2.2 To find the efficiency of Model of Analytical thinking Skill

2.3 To find the students' training effectiveness after using the Model of Analytical Thinking Skill Training.

2.4 To find the students' satisfaction towards the Model of Analytical Thinking Skill Training. 


\section{Methodology}

\subsection{Samples}

3.1.1 The samples for finding the quality of the test were 40 first year students majoring in computer science in the first semester of the academic year 2010 at Muban Chom Bueng Rajabhat University.

3.1.2 The samples for finding efficiency of the model, students' training effectiveness and students' satisfaction were purposive Sampling of 34 second year students majoring in computer science in the first semester of the academic year 2010 at Muban Chom Bueng Rajabhat University.

\subsection{Research Procedure}

This research constructed three things as follows:

\subsubsection{Construction of model of analyt- ical thinking skill training:}

In this step, the researchers took all five training steps from the Model of Analytical thinking Skill Training Process shown at above. The content of the model was synthesized from the Sternberg's intellectual theory and the Bloom's principles of Analytical Thinking. The Sternberg's intellectual theory has four aspects: verbal, quantitative, figural, and problem solving. [3]. The Bloom's principles of Analytical Thinking compose of analysis of elements, analysis of relationships and analysis of organizational principles [4].

The researchers developed three skill training sets. All three sets had difference in the three level of difficulty as simple intermediate and very difficult level in priority. In each set, there were four activities. Thus, there were 12 activities all together. To find out the reader reliability and content validity of the training sets, the research randomly selected 10 second-year students in com- puter science at Muban Chom Bueng Rajabhat University.

\subsubsection{Construction of the test of the analytical thinking skill:}

For constructing the test, the researcher referred the content from the sub-theory on intellectual of Sternberg and the Bloom's principles in Analytical Thinking. The test is divided into four aspects: verbal, quantitative, figural, and problem solving. The research made 45 multiple choice questions for the test. The researchers got three instructors at Muban Chom Bueng Rajabhat University to check the index of consistency (IOC) of the test.

\subsubsection{Construction of the questionnaire of students' satisfaction:}

The researchers constructed the questionnaire of students' satisfaction towards the model of analytical thinking skill training process. There are nine questions in the questionnaire.

\subsection{Experimental Design}

The researcher used the One-Group Pretest Posttest Design as follow:

\begin{tabular}{|c|c|c|c|}
\hline Group & Pretest & Treatment & Posttest \\
\hline $\mathrm{E}$ & $\mathrm{T} 1$ & $\mathrm{X}$ & $\mathrm{T} 2$ \\
\hline
\end{tabular}

E represented Experimental Group.

T1 represented Pretest

T2 represented Posttest

$\mathrm{X}$ represented Treatment

\subsection{Data Collecting Method}

The researcher spent five days to evaluate the model of the analytical thinking skill training process as detail shown in Table 1. 
Table 1: Schedule of collecting data of the model experiment

\begin{tabular}{|c|c|c|}
\hline & $\begin{array}{l}\text { Students' } \\
\text { Activities }\end{array}$ & $\begin{array}{l}\text { Data Col- } \\
\text { lected from } \\
\text { students }\end{array}$ \\
\hline Day 1 & $\begin{array}{l}\text { Introduce objectives } \\
\text { of the model evalua- } \\
\text { tion. }\end{array}$ & $\begin{array}{l}\text { Test scores } \\
\text { before train- } \\
\text { ing }\left(\mathrm{E}_{\mathrm{pre}}\right)\end{array}$ \\
\hline $\begin{array}{l}\text { Day } 2 \\
\text { (full } \\
\text { day) }\end{array}$ & $\begin{array}{l}\text { Doing the model } \\
\text { experiment. } \\
\text { - Students using the } \\
\text { training Set } 1 \\
\text { (simple difficul- } \\
\text { ty level) } \\
\text { - Doing 20 item } \\
\text { Quiz }\end{array}$ & $\begin{array}{l}\text { Tests core } \\
\text { Quiz } 1\left(\mathrm{E}_{1,1}\right)\end{array}$ \\
\hline $\begin{array}{l}\text { Day } 3 \\
\text { (full } \\
\text { day) }\end{array}$ & $\begin{array}{l}\text { Doing the model } \\
\text { experiment (contin- } \\
\text { ued) } \\
\text { - Students using the } \\
\text { training Set } 2 \\
\text { (moderate diffi- } \\
\text { culty level) } \\
\text { - Doing 26 item } \\
\text { quiz }\end{array}$ & $\begin{array}{l}\text { Test score } \\
\text { Quiz } 2\left(\mathrm{E}_{1,2}\right)\end{array}$ \\
\hline $\begin{array}{l}\text { Day } 4 \\
\text { (full } \\
\text { day) }\end{array}$ & $\begin{array}{l}\text { Doing the model } \\
\text { experiment (contin- } \\
\text { ued) } \\
\text { - Students using the } \\
\text { training Set } 3 \\
\text { (very difficult } \\
\text { level) } \\
\text { - Doing } 20 \text { item } \\
\text { quiz }\end{array}$ & $\begin{array}{l}\text { Test score } \\
\text { Quiz } 3\left(E_{1-3}\right)\end{array}$ \\
\hline Day 5 & $\begin{array}{l}\text { - Doing } 45 \text { item } \\
\text { Pretest } \\
\text { - Answer the ques- } \\
\text { tions on the stu- } \\
\text { dents, satisfac- } \\
\text { tion question- } \\
\text { naire }\end{array}$ & $\begin{array}{l}\text { 1. Test score } \\
\text { post- } \\
\text { test }\left(\mathrm{E}_{2} / \mathrm{E}_{\mathrm{pos}}\right. \\
\text { t) } \\
\text { 2. Evaluation } \\
\text { of the re- } \\
\text { sult on stu- } \\
\text { dents' sa- } \\
\text { tisfaction }\end{array}$ \\
\hline
\end{tabular}

\section{Research Results}

\subsection{The result of constructing the test of the analytical thinking skill}

The researcher referred to the principle of sub theory of the Sternberg's intellectual theory and Bloom's Analytical thinking Principle. The test was divided into 4 parts based on Sternberg's analytical thinking characteristics: verbal, quantitative, figural and problem solving. There were 147 items as shown in Table 2

Table 2: Number of questions classified by Sternberg's analytical thinking characteristics

\begin{tabular}{|c|c|c|}
\hline \multirow{2}{*}{$\begin{array}{l}\text { Sternberg's Analytical } \\
\text { Thinking Characteristics }\end{array}$} & \multicolumn{2}{|c|}{$\begin{array}{l}\text { Number of } \\
\text { Questions }\end{array}$} \\
\hline & Constructed & $\begin{array}{l}\text { Selected } \\
\text { for testing }\end{array}$ \\
\hline $\begin{array}{l}\text { 1. Verbal } \\
\text { 1.1. Analyze the word } \\
\text { meaning but the } \\
\text { word didn't have } \\
\text { the meaning } \\
\text { 1.2. Analyze differences } \\
\text { 1.3 Analyze similarities } \\
\text { 1.4 Analyze opposition } \\
\text { 1.5 Analyze prediction } \\
\text { 1.6 Analyze suborder } \\
\text { 1.7 Analyze the same } \\
\text { type of membership }\end{array}$ & $\begin{array}{l}9 \\
9 \\
9 \\
6 \\
6 \\
6\end{array}$ & $\begin{array}{l}2 \\
2 \\
2 \\
2 \\
2 \\
2\end{array}$ \\
\hline 2. Quantitative & 32 & 10 \\
\hline 3. Figural & 29 & 10 \\
\hline $\begin{array}{l}\text { 4. Problem Solving } \\
\text { 4.1 Problem Solving with } \\
\text { multiple choices } \\
\text { 4.2 Problem Solving with } \\
\text { essay type answer }\end{array}$ & $\begin{array}{l}29 \\
12 \\
17\end{array}$ & $\begin{array}{l}10 \\
4\end{array}$ \\
\hline Total & 147 & 45 \\
\hline
\end{tabular}

\subsection{The results of content validity, dif ficulty level (P) and discrimination power (D) of the test}

The researchers invited three instructors at Muban Chom Bueng Rajabhat University to do the consistency of content (IOC). The results showed that all 147 questions had the IOC value between 0.5 1.0. The difficulty value of questions was between $0.20-0.77$. The discrimination power value of all questions was above 0.2 . These results showed that 147 ques- 
tions could be used for the module evaluation.

\subsection{Results of Test Reliability}

The analysis of test reliability was done by Kuder Richardson's Internal Consistency (KR 20). The result of Test Reliability showed that the reliability values of all four parts of the test were above 0.80 as detail shown in Table 3.

Table 3: Reliability values of the test

\begin{tabular}{|l|c|c|}
\hline $\begin{array}{c}\text { Sternberg's Ana- } \\
\text { lytical Thinking } \\
\text { Characteristics }\end{array}$ & $\begin{array}{c}\text { Test } \\
\text { Relia- } \\
\text { bility }\end{array}$ & Results \\
\hline 1. Verbal & 0.96 & $\begin{array}{c}\text { Having } \\
\text { Reliability }\end{array}$ \\
\hline 2. Quantitative & 0.92 & $\begin{array}{c}\text { Having } \\
\text { Reliability }\end{array}$ \\
\hline 3. Figural & 0.92 & $\begin{array}{c}\text { Have Re- } \\
\text { liability }\end{array}$ \\
\hline $\begin{array}{l}\text { 4. Problem Solv- } \\
\text { ing Having } \\
\text { 4.1 Solving } \\
\text { Problems with } \\
\text { Multiple Choice } \\
\text { 4.2 Solving } \\
\text { Problem with } \\
\text { essay type answer }\end{array}$ & 0.88 & $\begin{array}{c}\text { Having } \\
\text { Reliability }\end{array}$ \\
\hline
\end{tabular}

\subsection{The efficiency of the model of ana- lytical thinking training}

The scores from each training set were analyzed as the efficiency during training $\left(E_{1}\right)$ and the scores from post-test were analyzed as the efficiency after training $\left(E_{2}\right)$. The efficiency criterion (E1/E2) of the model was set at $75 / 75$. From the Table 4 and 5, the efficiency during training values $\left(E_{1}\right)$ was 77.05 and the efficiency value after the training process $\left(E_{2}\right)$ was 78.82. These results showed that the efficiency of the model of analyt- ical thinking skill training was $77.05 /$ 78.82 which was above the criteria.

Table 4: The efficiency during training of the model of analytical thinking skill training $\left(\mathrm{E}_{1}\right)$

\begin{tabular}{|c|c|c|}
\hline $\begin{array}{c}\text { Training } \\
\text { Sets }\end{array}$ & $\begin{array}{c}\text { Score during } \\
\text { Learning } \\
\text { Process }\end{array}$ & $\begin{array}{c}\text { Effectiveness } \\
\left(\mathrm{E}_{1 \mathrm{i}}\right)\end{array}$ \\
\hline Set 1 & 497 & 73.08 \\
\hline Set 2 & 528 & 77.64 \\
\hline Set 3 & 547 & 80.44 \\
\hline & $\mathrm{E}_{1}$ & 77.05 \\
\hline
\end{tabular}

Table 5: The efficiency after training with the model of analytical thinking skill training $\left(\mathrm{E}_{2}\right)$

\begin{tabular}{|c|c|c|c|c|}
\hline List & $\begin{array}{c}\text { No. of } \\
\text { students }\end{array}$ & $\begin{array}{c}\text { Composite } \\
\text { Scores }\end{array}$ & $\begin{array}{c}\text { Total } \\
\left(\Sigma X_{\mathrm{i}}\right)\end{array}$ & $\begin{array}{c}\text { Effectiveness } \\
\left(\mathrm{E}_{2}\right)\end{array}$ \\
\hline $\begin{array}{c}\text { Posttest } \\
\text { scores }\end{array}$ & 34 & 1530 & 1206 & 78.82 \\
\hline
\end{tabular}

\subsection{The results of students' training effectiveness}

The scores from the experiment were analyzed for Pre-test and Post-test mean. The means were compared by using the statistics of Dependent T-test in order to find the students' training effectiveness after using the model as the detail shown in Table 6.

Table 6: The students' training effectivenes

\begin{tabular}{|c|c|c|c|c|c|}
\hline Results & $\begin{array}{l}\text { Total } \\
\text { Scores } \\
\left.\Sigma X_{i}\right)\end{array}$ & $\bar{x}$ & SD & $\mathrm{t}$ & Sig \\
\hline Pre-Test $\left(\mathrm{E}_{\mathrm{pre}}\right)$ & 533 & 15.67 & 2.33 & \multirow{2}{*}{30.277} & \multirow{2}{*}{.000} \\
\hline Post-Test ( $\left.\mathrm{E}_{\text {post }}\right)$ & 1206 & 35.47 & 3.23 & & \\
\hline
\end{tabular}

From the Table 6, the Pre-test mean was 15.67 and the Post-test mean was 35.47. The comparison of the Pre-test mean and the Post-test mean showed that it was significantly different at Level .01. These results showed that the model of analyti- 
cal thinking skill training was able to make the students have the higher training effectiveness in analytical thinking skill.

\subsection{The results of the students' satis- faction}

The answers from the students' satisfaction questionnaire were analyzed by using mean and standard deviation. The conclusion of the students' satisfaction towards the model of analytical thinking skill training process was in the high level with $\bar{x}=4.03$ and the standard deviation $=0.35$ as detail shown in the table.

Table 7: Summary of Means, Standard Deviation, and Level of students' Satisfaction towards the Model of Analytical Thinking Skill Training

\begin{tabular}{|l|l|l|c|}
\hline \multicolumn{1}{|c|}{ Contents } & $\bar{x}$ & SD. & $\begin{array}{c}\text { Level of } \\
\text { Students' } \\
\text { Satisfaction }\end{array}$ \\
\hline $\begin{array}{l}\text { 1. Ideas of Model of } \\
\text { Analytical Thinking } \\
\text { Skill Training } \\
\text { Process }\end{array}$ & 3.64 & 0.59 & High \\
\hline $\begin{array}{l}\text { 2. Purposes of Thinking } \\
\text { Skill Training Process }\end{array}$ & 3.79 & 0.73 & High \\
\hline $\begin{array}{l}\text { 3. Analytical Thinking } \\
\text { Skill Training } \\
\text { Through Activated } \\
\text { Coaching Process }\end{array}$ & 4.53 & 0.50 & $\begin{array}{l}\text { Very } \\
\text { High }\end{array}$ \\
\hline $\begin{array}{l}\text { 5. Warm up } \\
\text { Advise by Demon- } \\
\text { strating the Skill }\end{array}$ & 3.74 & 0.37 & High \\
\hline $\begin{array}{l}\text { 6. Analytical Thinking } \\
\text { Skill Development } \\
\text { Activity Process } \\
\text { Techniques through } \\
\text { D.M.I.H. Process }\end{array}$ & 4.62 & 0.09 & Very \\
\hline $\begin{array}{l}\text { 7. Training by Advis- } \\
\text { ing Learner through } \\
\text { Step by Step Coach- } \\
\text { ing }\end{array}$ & 4.13 & 0.52 & High \\
\hline $\begin{array}{l}\text { 8. Training Learner } \\
\text { Through Full Step } \\
\text { Coaching }\end{array}$ & 4.19 & 0.51 & High \\
\hline 9. Evaluation & 3.76 & 0.33 & High \\
\hline Conclusion & 0.03 & High \\
\hline
\end{tabular}

\section{Conclusion}

The Model of Analytical Thinking Skill presented in this research was been considered as one of the training innovation in Thailand. It can be implemented and applied to solve the problem of Analytical thinking Skill of the students studying in computer programming. It can be used to train students before or integrated during the training process.

\section{References}

[1] Doctoral degree dissertation, Innovation Learning in Technology program, Faculty of Industrial Education and Technology, King Mongkut's University of Technology Thonburi, 2009, Thai Vocational Education 2030 Educational Conference and Seminar Siam City Hotel, June 23, 2009, Bangkok pp. 97-98.

[2] S. Montaku, P. Kaittikomol, and P. Tiranathanakul, The Model of Analytical Thinking Training Process, Research Journal of Applied Sciences, volume7, January 2012, pp. 17-20.

[3] R.J. Sternberg, 1994, Diversifying Instruction and Assessment, The Educational Forum. Vol. 59. p.51

[4] B.S. Bloom, Taxonomy of Education Objectives, The Classification of Educational Goals, Longman group, U.K., ISBN-13: 978-0679302117. 